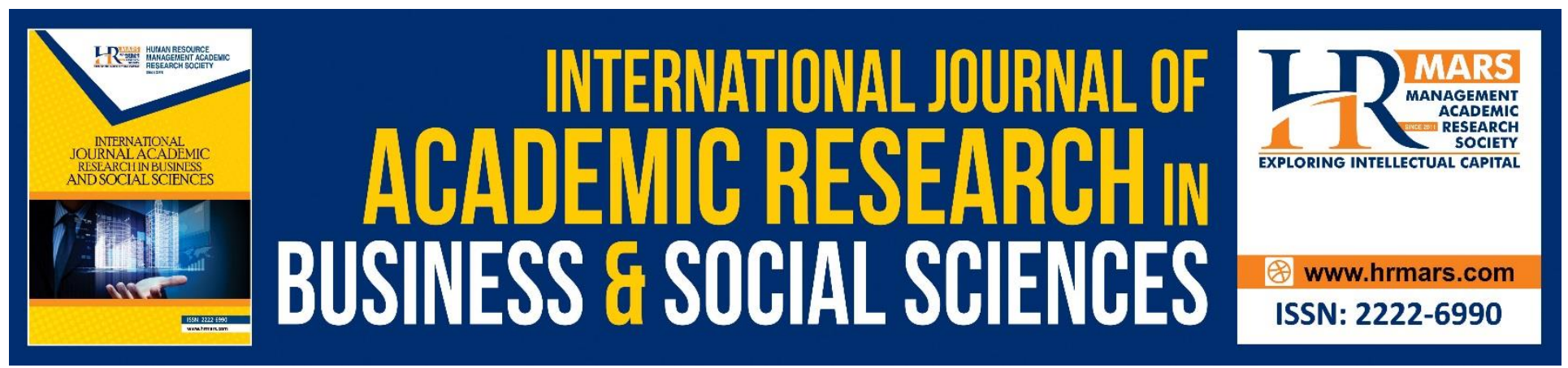

\title{
The Malay Identity in Malaysian Women's Paintings
}

Liza Marziana Mohammad Noh, Abdul Rauf Ridzuan, Nurkhazilah Idris, Tengku Intan Suzila Tengku Sharif and Khairunnisa Mohd Abdul Ghani

To Link this Article: http://dx.doi.org/10.6007/IJARBSS/v8-i10/4708 DOI: $10.6007 /$ IJARBSS/v8-i10/4708

Received: 17 Sept 2018, Revised: 23 Oct 2018, Accepted: 26 Oct 2018

Published Online: 29 October 2018

In-Text Citation: (Noh, Ridzuan, Idris, Sharif, \& Ghani, 2018)

To Cite this Article: Noh, L. M. M., Ridzuan, A. R., Idris, N., Sharif, T. I. S. T., \& Ghani, K. M. A. (2018). The Malay Identity in Malaysian Women's Paintings. International Journal of Academic Research in Business and Social Sciences, 8(10), 63-72.

Copyright: (c) 2018 The Author(s)

Published by Human Resource Management Academic Research Society (www.hrmars.com) This article is published under the Creative Commons Attribution (CC BY 4.0) license. Anyone may reproduce, distribute, translate and create derivative works of this article (for both commercial and non-commercial purposes), subject to full attribution to the original publication and authors. The full terms of this license may be seen at: http://creativecommons.org/licences/by/4.0/legalcode

Vol. 8, No. 10, 2018, Pg. 63 - 72

Full Terms \& Conditions of access and use can be found at http://hrmars.com/index.php/pages/detail/publication-ethics 


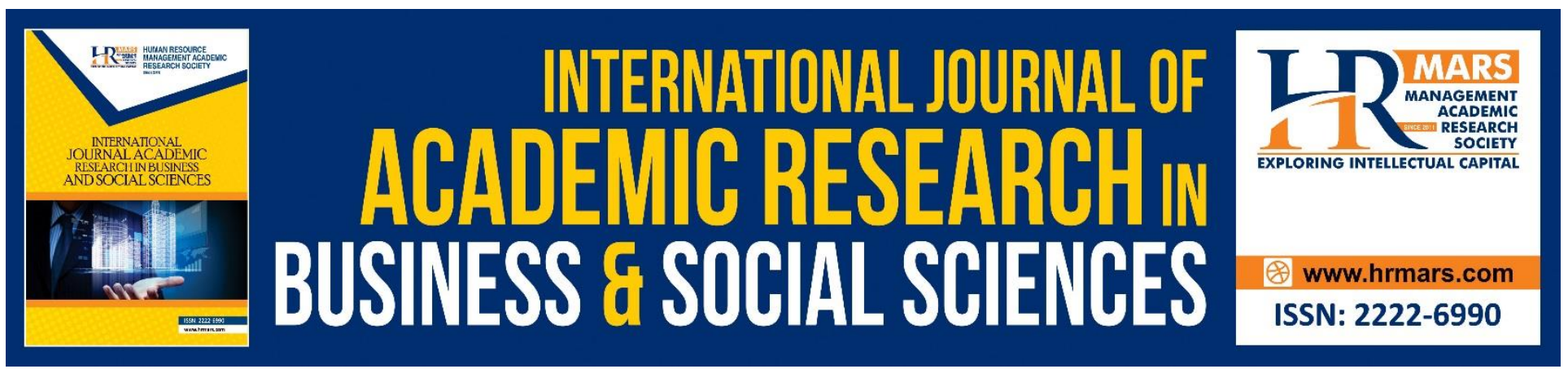

\title{
The Malay Identity in Malaysian Women's Paintings
}

\author{
Liza Marziana Mohammad Noh ${ }^{1}$, Abdul Rauf Ridzuan², Nurkhazilah \\ Idris $^{3}$, Tengku Intan Suzila Tengku Sharif ${ }^{4}$ and Khairunnisa Mohd \\ Abdul Ghani ${ }^{5}$ \\ $1,2 \& 3$ Faculty of Arts and Design, Universiti Teknologi MARA Melaka, Malaysia \\ ${ }^{4}$ Academy of Language Studies, Universiti Teknologi MARA Pahang, Malaysia \\ ${ }^{5}$ Faculty of Arts and Design, Universiti Teknologi MARA Shah Alam, Malaysia
}

\begin{abstract}
The Malaysian women's identity in paintings essentially began to surface between the year 1970's to 1980 's. The attempt to fulfill the demand of identity searching fought by the Malay painters in the 1958 has enlightened the present women revivalists to also pursue this quest. This was leaded by the severe identity crisis suffered by Malaysian women painters of 1950's to the 1970's. Thus, by reevaluating the essence of 'Malayness' and its cultural strand, the Malaysian women painters tempt to portray an identity to complement the Malay arts. The objective of this paper is to examine the Malay identity in Malaysian women's painting by studying the form and content of Malaysian women's painting by using art appreciation descriptive method. Visual content analysis is conducted to achieve the objectives above. The outcome of this paper shall suggest the emergence of Malay arts and cultural heritage values traceable in the Malaysian women's paintings between the 1970's to the 1990's. Adopting the heritage arts discipline, the present article shall unfold the identity of 'Malayness' through its form and content in each painting.
\end{abstract}

Keywords: Identity, Malayness, Malay Arts and Cultural Heritage, Form, Content

\section{Introduction}

The Malays has battled the quest for a cultural identity in Malaysia since the 1956 until Malaysia's independence (Liza Marziana, 2014). The concerns over the possibility of losing the values of Malay cultural heritage to westerns influences was justified as some impact on the Malay visual arts is already apparent (Piyadasa, 2000). With that, the Malays leaded the quest for a stronger identity. The rejection of Malay cum Islamic ethos was evidential in Malay visual arts (Sulaiman, 2012). Nonetheless, the elements of secularism and materialism in Malays' paintings began to surface (Sulaiman, 2012). This may indicate that Malay arts and cultural values were without appropriate planned artistic wave. The Malay values were suppressed and Malay painters were without identity 
INTERNATIONAL JOURNAL OF ACADEMIC RESEARCH IN BUSINESS AND SOCIAL SCIENCES

Vol. 8, No. 10, Oct. 2018, E-ISSN: 2222-6990 @ 2018 HRMARS

and ideas became impeded. The result of this soul conflict and identity confusion among the Malay painters of 1930's to late 1960's has encouraged them to begin an identity quest in the 1970's. This quest was also sparked by the establishment of the National Cultural Congress in 1971 by the Sports and Youth Ministry at Malaya University (Muliyadi, 2001). The establishment had indirectly encouraged the painters to attempt to incorporate Malay themes into their paintings. The mission of the congress was to seek a new formula and to focus on molding a multi-ethnicity national culture (Muliyadi, 2001). It had achieved three main essential concepts in creating a Malaysian national culture.

\section{Theoretical concepts}

The three main concepts to a Malaysian national culture are: firstly, the Malaysian national culture has to be the local regional culture. Secondly, elements of other cultures that are suitable can be incorporated into the national culture. Thirdly, Islam is main element of the national culture (Muliyadi, 2001).

\section{Malayness}

Based on these concepts, Malay painters began to analyze and synthesize the Malay arts and culture heritage which indirectly had paved a new artistic wave (Siti Zainon, 2012). This portrayed a fight to sustain a self-identity and strengthen the cultural heritage. Wharton identified that the Malay artistic wave was evidential between the year 1958-1964 even without "a Malayan school of painting (Dzulhilmi, 2006)." This brave quest was also internationally traceable at the Contemporary World Art. The 'Akar-Akar Peribumi (Heritage Roots) Seminar' which was held at Institut Teknologi Mara (ITM), Shah Alam in 1979 had also witnessed the emergence of an artistic cultural identity from revivalist Malay painters who realized the need for an identity in Malay visual arts (Piyadasa, 2000). Malay revivalist painters who majority were ITM trained had sparked a new visual arts portrayal by referencing their arts to Malay artistic elements such as the 'songket' and 'batik' motives, fables and legends, and Malay social issues from literary texts (Muliyadi 2001). These revivalists had also expanded their artistic ideology by making references to Islamic Aesthetic. This added Islamic values to their identity enabled them to express their souls as Muslim painters (Ahmadrashidi, 2010).

\section{Malay Women painters}

In the effort to build the national arts identity, the role of female Malay revivalist painters was also apparent. Ruzaika Omar Basaree, Khatijah Sanusi, Fatimah Chik and Mastura Abdul Rahman are the women artists who contributed to the attempt to reflect the national cultural identity. Their works have channeled the Malay arts to its glory as their perspective to achieve the national arts did not emerge from 'brain drained' moments but rather from intellectuality and gracefulness of Malay female painters. These elements were wrapped in their souls and hearts that they managed to present an artistic perspective view of critical visions of nature, cultural and religion. The arts presented by these Malay artists has high references to the usage of Malay traditional images such as motives from wood carvings, traditional Malay textiles such as batik and traditional weavings and the Arabs images from Islamic arts. This further certifies the soft touches of the female Malay painters whose emphasis were on fragility, methods adopted and meaning relayed (Liza Marziana, 2013). 
INTERNATIONAL JOURNAL OF ACADEMIC RESEARCH IN BUSINESS AND SOCIAL SCIENCES

Vol. 8, No. 10, Oct. 2018, E-ISSN: 2222-6990 @ 2018 HRMARS

\section{Problem Statement}

For more than 55 years, the existence of arts images has witnessed most local artists being greatly influenced by western styles and neglected their local identity (Liza Marziana, 2013). Thus, with the manifestation of Malay images from the Malay Culture, the awareness towards the national arts had started to appear among the local artists particularly in the 1970's and the following years. However, it did not receive much attention as there had not been any serious work done to document this transformation. Furthermore, the tendency of new generation artists towards universal styles had further contributed to the abandonment and less emphasized on the Malay art and cultural heritage symbols (Dzulhaimi, 2006).

\section{Objectives}

The main objective of this study is to examine the Malay identity in Malaysian women's painting through the study of the form and content of Malaysian women's painting. Secondly, to certify the Malaysian national culture theoretical concepts are achieved in the samples.

\section{Methodology}

This study adopts the observation method and focuses on the content analysis on the chosen painting samples. D'Avella mentioned, "careful looking is one of the two basic tool of art history (2010: 51)." Therefore, structured, systematic and careful observation, were adopted to produce artistic data which derived from Malay images. This method enables the researchers to enriched the visual arts with detailed observations and search. This allows identification of the images and expansion of knowledge on these images using arts appreciation descriptive method. Visual content analysis is then carried out. Codes are based on the theoretical concepts mentioned above.

Four paintings by Malay women painters were chosen as samples of this study. These samples were obtained from the data document of the permanent national "Warisan Seni Tampak (Visible Arts Heritage)" inventory collection from 1958 to 2003 published by the National Visual Arts. This data document is of Malay culture images. The criteria for sampling are the artist, the art, year, title and Malay images. Therefore, the present paper focuses on the discussion of the Malay arts and cultural heritage values on female arts within the 1970's till the 1990's. Art appreciation descriptive method based on the art history discipline will be adopted to identify the Malay arts and cultural heritage that were surfaced by the female revivalists in their presentations. According to Ahmadrashidi (2012) art appreciation is part and parcel of the art history discipline. Arts and art appreciation depend on each other to make art meaningful. Art history cannot exist without art appreciation and vice versa. Art History functioned on the analysis of the origin, development, changes and the downfall of art styles.

\section{Data Analyzing}

To discuss Malay arts and culture images where the Malay artists' identity lies, the arts appreciation method (Rosalind, 2005) is adopted. Three basic features that builds the forms and content are the subject, compositions and meaning in appreciating an art. Ocvirk, Stinson, Wigg, Bone \& Clayton (2009) also stressed subject, form, and meaning are essential criteria in analyzing an art work. The 
INTERNATIONAL JOURNAL OF ACADEMIC RESEARCH IN BUSINESS AND SOCIAL SCIENCES

Vol. 8, No. 10, Oct. 2018, E-ISSN: 2222-6990 @ 2018 HRMARS

art appreciation method will be applied on four pioneering women Malay revivalists' work of arts. They are Ruzaika Omar Basaree, Fatimah Chik, Khatijah Sanusi, and Mastura Abd Rahman. These painters are among the earliest revivalists who fought for arts and cultural heritage (Liza Marziana, 2013). These painters have been and are among the painters who consistently portray Malay images and themes in their works.

\section{Findings and Discussion}

Since the organizing of the National Cultural Congress in 1971, local artists have actively revived the Malay arts and cultural.

Ruzaika Omar Basaree is a Malay female painter who receive initial artistic exposure locally and abroad. She is the pioneer to a new approach in local art works. Through her early works in the 1970's, she has shown the tendency towards using the arts and cultural heritage as a medium to define the wordly view of Malay. This was done through her "Siri Dungun-Jendela Terbuka" (1978), "Siri Dungun-Jendela III" (1979) and "Siri Dungun"(1981).

Fig. 1 is an example of Ruzaika artwork which most of them adopted the Malay traditional architectural. The Terengganu traditional carving motives known as "kerawang" was used in her paintings. This corresponds to theoretical concept 1 . The combination of these motives were presented through an attempt to the nature of the paintings which is traditionally defined by color arrangement on two dimensional surface that has been described in three dimensional approach. This wide painting definition was pioneered by Ruzaika and she was certified as the first Malay female who approach paintings through three dimensional approach. This is accepteable according to theoretical concept 2.

Ruzaika then went in-depth into Islam Aesthetic values based on her references towards Malay carving philosophy that is the "awan larat' concept which has an excellent meaning in the Islamic Aesthetic values. This tallied with theoretical concept 3. Ruzaika's appreciation towards nature, Malay architectural design and her realizations towards tawheed and aqidah that do not defy Allah was clearly translated her Malay view that arts is based on culture and religion. Thus, Ruzaika can be categorized as a Malay female painter who brought symbolic paintings style that represent shape and meaning literally and artistically. This is confirmed by Syed Ahmad Jamal "...Rozaika Omar Basseri in Dungun Series, "Window Within Window'" become established in Malaysia imagery. The traditional element, which Rozaika has successfully incorporated in her 'Siri Dungun', has resulted in a work that's truly Malaysian. It is a masterpiece of Malaysian art image (Kanansky, 1988)." 


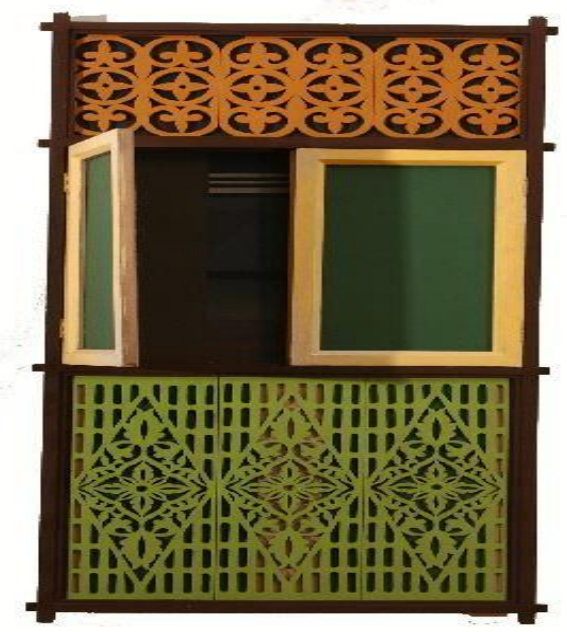

Fig.1. Ruzaika Omar Basaree. Dungun Series. Mixed Media. (1981). 17.08 x76 cm

Next is Khadijah Sanusi whose art works emerged in the 1970 and remained active until the 1990's. Fig. 2 shows one of her September Series works. She was also locally and trained abroad which contributed to her Malay Islamic inspirations. Although presented universal themes in her September Series II (1992), she adopted floral motives that were borrowed from Malay floral motives and Islamic geometrical. This has portrayed the shape, soul and her Malay Islamic identity. These evidences measure to theoretical concept 1 and 3 . The national cultural congress was the driving force to Khadijah Sanusi to unfold the question of national identity that has also created conflict in her soul and thoughts around the year 1980's and 1990's. Her creative process was inspired by the famous Malay batik traditional arts media and techniques. She experimented this as a realization of her fight to build a national identity through paintings. Her attempt to recall her memory of September in a Malay and Islamic Aesthetic approach had successfully been portrayed in a harmonious way. Her work of arts was categorized as an abstract work that is expressed in a decorative and symbolist in nature.

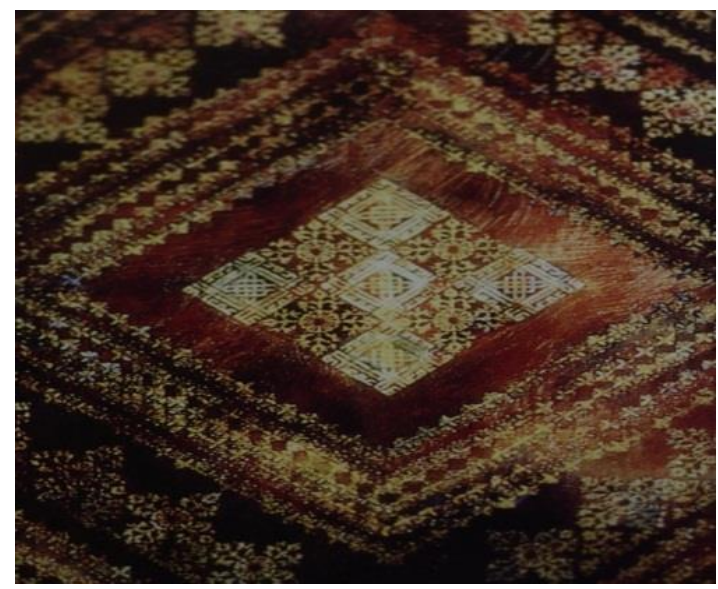

Fig.2. Khatijah Sanusi. September Series II. Batik Painting. (1992). 126cm x $180 \mathrm{~cm}$ 
Fatimah Chik, on the other hand, was trained in the area of textile arts at ITM and initially worked at a batik factory. She was very impressed with the traditional textile arts that it had influenced her works where she incorporated these influences in most of her paintings. Fig. 3 above is a clear matched to theoretical concept 1. Fatimah Chik's references on Malay traditional motives had defined her broad overview on Malay and its cultural beauty as created by tribal artists of the Malay Archipelago. Unity in Harmony (1996) depicted Fatimah's creative process in appreciating the Malay Archipelago elements by using printing blocks, wax and cautious dipping techniques. This creative process represented a new technique application and material used in Malay modern paintings. It had also replaced western traditional colorings materials such as water, oil or acrylic based colors. Fatimah Chik's works is accepted as depicting Malay's flavor as her archipelago motives and batik techniques application defined Malays. Fatimah's works was also categorized as decorative abstract art that have symbolic values. This was visible in her usage of triangle organic motives which represented by repetitive mountain motives embraced in her work. The repetitiveness leaded its viewers to zigzags movements that may stimulate further appreciations. This is allowed in theoretical concept 2. The inter-woven effect from printing creations and color applications portrayed Fatimah's soul and her appreciation towards cultural textile and worldly views through native archipelago.

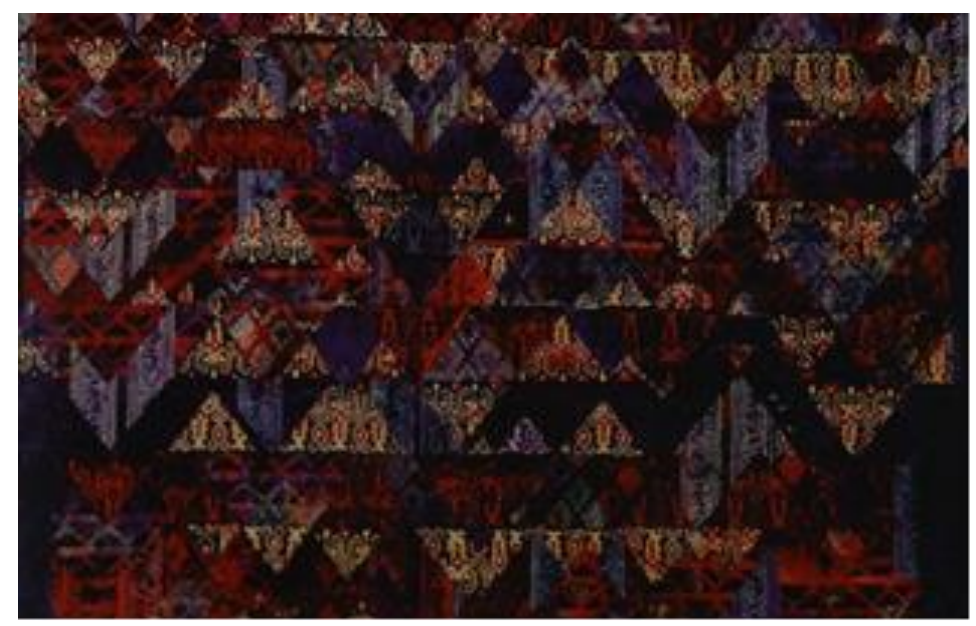

Fig. 3. Fatimah Chik. Unity in Harmony. Batik painting and collage. (1996). $140 \mathrm{~cm} \times 170 \mathrm{~cm}$

Next is Mastura Abdul Rahman. She is a young generation painter who started paintings in the 1980's. She was trained at the ITM studying fine art. Currently lecturing at the Multimedia University, she is actively involved in the revivalists' movement that has recalled her in identity searching rooted to the Malay worldly view in producing her works. Therefore, most of her works fulfilled the Malay flavors. Her works are categorized as decorative arts which are inspired by the Malay-Islamic cultural contexts. Her educational exposures to western theories have also inspired her to incorporate western ideas such as using aerial perspective to present an unconventional artistic idea of space.

Fig. 4 was a large size work of art and represented a complex arrangement of artistic elements. Like her other works she translated the Malay worldly view from a female perspective. Women are 
closely attached to elements of beauty and kinship. These have also inspired Mastura to visualize the women's world through her paintings. To represent nature, she borrowed songket motives and traditional batik to fill the paintings' background. These motives are colored using fresh and contrasting colors thus creating harmonious environment to the painted motives. Mastura constructed lines diagonally to express an aerial perspective. This assisted in portraying an internal decoration of a typical traditional Malay house. The lines were positioned in 45 degrees to create dynamic and tension visual effect. This technique made Mastura works unique and holds definite strength. This attempt has enabled her to create a flattened into a two-dimensional piece with an emphasis on the ornamentations. She unified ornaments that symbolizes such as Malay baby cradle, newspaper, sarong, congkak as well as labu sayung, making her work significant. This hinted her love for Malay culture and objects and corresponding to theoretical concept 1.

Masture also included objects that signify Islamic elements such as Quran, Yassin books and praying mat. These objects were placed on a palm-woven mat while the praying mat was placed on a classic wooded beam. This incorporation made her manifestation of Islamic values visible. These suited theoretical concept 3. In short, Mastura successfully showed the beauty of ornaments from the Malay culture which are embedded with Islamic concepts and teachings. Thus, her work may be simplified as gynocritics as she portrays female artistic paintings with Malay characteristics which permitted by theoretical concept 2. Piyadasa (2002:20) has stressed that the "incorporation of both the Malay-Islamic element was essential and vital to the formation of harmonious and peaceful life style." Thus, theoretical concept 3 is accomplished.

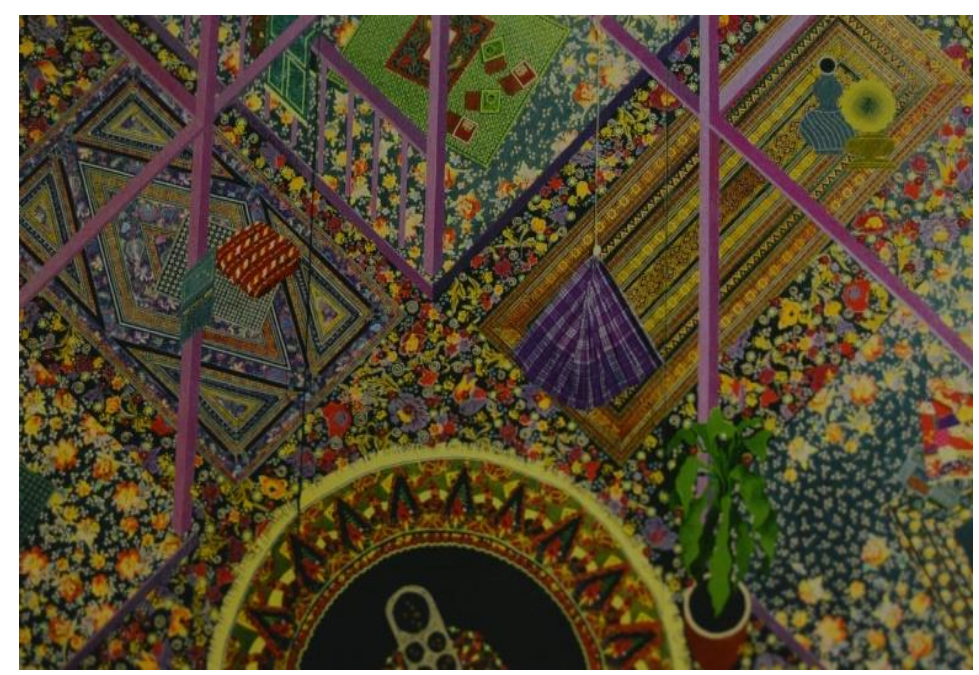

Fig. 4. Mastura Abd Rahman. House of Flower, House of Harmony. Mixed media and Collage. (1999). $183 \mathrm{~cm} \times 276 \mathrm{~cm}$

\section{Conclusion}

The sampling above clearly depicted the art and culture of Malay and Islamic Aesthetics by Malaysian women artists. The National Arts and Cultural Congress 1971 has established a framework which have paved the path to Malaysian women artists by redirecting their artistic focus to Malayness based on Islamic fundamentals. All the described artworks are of descriptive appreciation as the floral adopted 
images are filled with Malay elements while the geometrical shapes are of Islamic aesthetics that have been neutralized and dematerialized.

These have produced traces of decorativeness. The above samples are not stagnant yet have underwent multiple process of revitalizations and newly adopted approaches from the technical and medium perspectives. Thus, it is apparent that the soul and forms of these Malay women arts have the intellectual values and advance sensitivity towards refining their views and demands of the Malay world. These complements the need for a modern art form. The artists' wise images selections of Malay and Islamic elements have shown their intellectually where they have abled to merge the western and traditional approaches in their presentations. These have also displayed their exceptional ability to combine Islamic and contemporary elements.

In conclusion, the major findings of the present study include firstly, the analyzed samples have fulfilled the theoretical elements of Malay arts, and secondly, it unfolds several criteria added to Malay arts by female touches. The feminine touches in arts have revealed the celebrated Malay female softness for instance tediousness, refinements and politeness. Their essence of diligence is also visible. In this matter, it is thus documented that Malayness has become the identity of Malay women arts and the National art culture concepts have been attained. This arrived at the objectives and the problems that drive the present study.

\section{Recommendation}

The present study sets to certify the Malaysian national culture theoretical concepts achieved in the female Malay arts. Together with this, it discloses several criteria supplementary to Malay arts by feminine touches. Future studies may include the study on this female softness which among others comprise of tediousness, refinements and politeness. Other yardsticks of gender skewedness may be reviewed alongside other elements especially features of modern contemporary Malay, liberal Malays or new Malays which demand examination too. These also necessitate documentations for study, preservation and revitalization.

\section{References}

Hasan, A. (2012). Contemporary Islamic painting in Malaysia 1980 to 2000. Shah Alam: Penerbit Press Universiti Teknologi Mara.

Hasan, A. (2010). Islamic art of the Malay world. Melaka: Faculty of Art and Design.

D’Avella, A. (2010). Methods and theories of art history. $2^{\text {nd }}$ Edition. London: Laurence King Publishing Ltd.

Kanansky, D. (1988). Contemporary painting of Malaysia. Kuala Lumpur: Balai Seni Lukis Negara Malaysia. Kuala Lumpur. 
INTERNATIONAL JOURNAL OF ACADEMIC RESEARCH IN BUSINESS AND SOCIAL SCIENCES

Vol. 8, No. 10, Oct. 2018, E-ISSN: 2222-6990 (C) 2018 HRMARS

Noh, L. M. M. (2014). Malay symbols in Malaysian visual art from 1970-

2003. Ist International Conference on Creative Media, Design \& Technology (REKA2014), Penang, Malaysia.

Noh, L. M. M. (2013). Manifestasi pandangan dunia Melayu dalam rupa dan jiwa seni catan wanita Melayu. Prosiding Seminar Penyelidikan Pemikiran \& Kepimpinan Melayu, pp.98-106

Zain, D. M. (2006). Seni Kontemporari Malaysia dalam Pembentukan Sejarah Tradisi. Suatu Penilaian Bentuk dan Makna. Persidangan Seni Budaya \& Warisan.Pendidikan Seni Budaya \& Warisan di Abad 21: Teori dan Praktis. Anjuran Kementerian Kebudayaan Kesenian dan Warisan, pp. 203-211.

Piyadasa, R. (2002). Masterpieces from the National Art Gallery of Malaysia. Kuala Lumpur: Balai Seni Lukis Negara.

Ocvirk, O.G, Stinson, R.E, Wigg, P.R, Bone, R. \& Clayton, D.L.2009. Art fundamentals: Theory and practice. $11^{\mathrm{TH}}$ Edition. New York: McGraw-Hill.

Ragans, R. (2005). Art talk. United States of America: Mc Graw Hill.

Ismail, S. Z. (2012). Menulis dan Melukis: "Writing" and "Drawing" in Malay traditional art and their impact in contemporary art-a Study of cultural values. In Nurhanim Khairuddin, Beverly Yong and T.K Sabapathy. Imagining Identities. Narratives in Malaysian Art (Vol.1, pp. 148-166). Kuala Lumpur: RogueArt.

Esa, S. (2012). An Islamic identity in contemporary Malaysian Art: Achievements and challenges. In Nurhanim Khairuddin, Beverly Yong and T.K Sabapathy. Imagining Identities. Narratives in Malaysian art (Vol. 1, pp. 224-24). Kuala Lumpur: RogueArt.

\section{Corresponding Author}

Liza Marziana binti Mohammad Noh

lizamarziana@ymail.com

Faculty of Art and Design

MARA University of Technology

Alor Gajah Campus

Jalan Lendu, 78000 